Article

\title{
Biocompatible Porous Polyester-Ether Hydrogel Scaffolds with Cross-Linker Mediated Biodegradation and Mechanical Properties for Tissue Augmentation
}

\author{
Berkay Ozcelik ${ }^{1}$, Jason Palmer ${ }^{2}$, Katharina Ladewig ${ }^{1}$, Paula Facal Marina 3,4 (iD,
} Geoffrey W. Stevens ${ }^{1}$, Keren Abberton ${ }^{2,+}$, Wayne A. Morrison ${ }^{2, \ddagger}$, Anton Blencowe ${ }^{3,4, * \text { (D) }}$ and Greg G. Qiao ${ }^{1, *}$

1 Department of Chemical \& Biomolecular Engineering, The University of Melbourne, Parkville, Melbourne, VIC 3010, Australia; ozcelikb@unimelb.edu.au (B.O.); kladewig@unimelb.edu.au (K.L.); gstevens@unimelb.edu.au (G.W.S.)

2 O'Brien Institute Department, St. Vincent's Institute of Medical Research, Melbourne, VIC 3065, Australia; jpalmer@svi.edu.au (J.P.); abberton@unimelb.edu.au (K.A.); wayne.morrison@unimelb.edu.au (W.A.M.)

3 School of Pharmacy and Medical Sciences, University of South Australia, Adelaide, SA 5000, Australia; Paula.FacalMarina@unisa.edu.au

4 Future Industries Institute, University of South Australia, Mawson Lakes, SA 5095, Australia

* Correspondence: anton.blencowe@unisa.edu.au (A.B.); gregghq@unimelb.edu.au (G.G.Q.); Tel.: +61-8-8302-2493 (A.B); +61-3-8344-8665 (G.G.Q.)

+ Current addresses: Murdoch Children's Research Institute, The Royal Children's Hospital, Parkville, Victoria 3052 Australia; The University of Melbourne, Department of Pediatrics, The Royal Children's Hospital, Parkville, Victoria 3052 Australia.

$\ddagger$ Current addresses: Department of Surgery, St Vincent's Hospital, The University of Melbourne, Parkville, Melbourne, Victoria 3010, Australia; Faculty Health Sciences, Australian Catholic University, Fitzroy, Melbourne, Victoria 3065, Australia.

Received: 15 January 2018; Accepted: 6 February 2018; Published: 12 February 2018

\begin{abstract}
Porous polyester-ether hydrogel scaffolds (PEHs) were fabricated using acid chloride/alcohol chemistry and a salt templating approach. The PEHs were produced from readily available and cheap commercial reagents via the reaction of hydroxyl terminated poly(ethylene glycol) (PEG) derivatives with sebacoyl, succinyl, or trimesoyl chloride to afford ester cross-links between the PEG chains. Through variation of the acid chloride cross-linkers used in the synthesis and the incorporation of a hydrophobic modifier (poly(caprolactone) (PCL)), it was possible to tune the degradation rates and mechanical properties of the resulting hydrogels. Several of the hydrogel formulations displayed exceptional mechanical properties, remaining elastic without fracture at compressive strains of up to $80 \%$, whilst still displaying degradation over a period of weeks to months. A subcutaneous rat model was used to study the scaffolds in vivo and revealed that the PEHs were infiltrated with well vascularised tissue within two weeks and had undergone significant degradation in 16 weeks without any signs of toxicity. Histological evaluation for immune responses revealed that the PEHs incite only a minor inflammatory response that is reduced over 16 weeks with no evidence of adverse effects.
\end{abstract}

Keywords: polyester-ether; hydrogel; scaffold; biocompatible; biodegradation

\section{Introduction}

3D scaffolds with appropriately engineered characteristics (e.g., mechanical properties, biodegradability, and tissue-material interactions) for the regeneration of tissues are central to the concept of tissue engineering. Regardless of whether the scaffolds are cultured in vitro with cells and then implanted 
into an injured site, or are implanted directly into the injured site to promote tissue regeneration in vivo from the host system, the requirements and challenges of scaffold engineering are well recognised [1-3]. For soft-tissue engineering, hydrogel scaffolds have displayed great promise as a result of their unique compositional and structural similarities that mimic those of the natural extracellular matrix (ECM) and provide a desirable framework for the proliferation and survival of cells. Nevertheless, both physicochemical and classical mechanical parameters, including the biodegradation, porosity, and surface chemistry, as well as biological performance parameters-biocompatibility and cell adhesion-must be tuned for specific applications. One of the major challenges is the optimization of all of these parameters in a single formulation. For example, improvements in the mechanical properties are generally at the detriment of the degradability. In addition, the accessibility and commercial feasibility also needs to be considered when developing scaffolds. Therefore, finding an optimal biomaterial that combines all the necessary characteristics for tissue regeneration remains a major objective of contemporary tissue engineering.

A wide range of natural and synthetic materials have been used to fabricate hydrogel scaffolds, as well as combinations thereof. In particular, poly(ethylene glycol) (PEG) derivatives have been extensively studied as they can be fabricated into hydrogels with tailorable mechanical and swelling properties matching various tissues types [4], and are generally considered bio-inert (i.e., non-immunogenic and anti-protein fouling). While the latter is not necessarily conducive to cell adhesion and tissue formation, various strategies have been reported to conjugate bioactive molecules to modulate specific cellular responses [5]. Numerous synthetic approaches have been devised for the preparation of covalently cross-linked PEG-based hydrogels [6] including radical polymerisation of PEG di(meth)acrylate macromonomers [7], Michael-type additions [8-10], and epoxy-amine [11], hydrazide-aldehyde [12], thiol-ene [13-15] and azide-alkyne chemistries [16,17] to mention a few. Furthermore, these approaches generally allow hydrolytically or enzymatically degradable components to be incorporated to afford biodegradable PEG-based hydrogels. Common approaches involve the modification of PEG derivatives with hydrolytically susceptible polyester and polycarbonate segments $[10,13,14,18-20]$, or the use of short peptide cross-linkers that can be degraded by specific enzymes $[8,9,21]$.

Evidently, the development of sophisticated PEG-based hydrogel systems-such as those described above-requires the synthesis and purification of suitable PEG precursors, cross-linkers and bioactive components to provide desirable physicochemical properties and cellular interactions. In general, these components need to be custom prepared, or if available commercially, are expensive. Thus, there remains significant interest in the development of PEG-based hydrogels with suitable tissue engineering characteristics from cheap and readily available commercial reagents without complex manufacturing steps. Furthermore, simplification of the materials and manufacture processes are likely to facilitate regulatory approval [22]. These aspects are particularly relevant to the manufacture of large volume scaffolds or high quantities of materials, such as those that might be required for tissue augmentation in plastic and reconstructive surgery after trauma (e.g., breast reconstruction) [23-25]. In these applications, it is desirable to have mechanically robust porous scaffolds that maintain their shape and volume, and guide tissue regeneration into the desired structure. This can be particularly challenging for soft tissues, as the material ideally needs to be hydrated and mimic the ECM mechanical properties, yet elastic and shape persistent to avoid fracture and throttling due to the stress caused by the collapse of the scaffold by the action of an external force. Indeed, individual cells can respond to changes in these stresses, varying from morphological alterations to changes in gene expression.

For breast reconstruction, various porous scaffolds have been tested ranging from additive manufactured rigid plastics [25-28] (e.g., poly(glycolide-co-lactide) [29]) to soft hydrogels (e.g., natural biopolymers [23,28], PEG [30-32], and poly(acrylamide) [33]). Although rigid plastics maintain their shape and volume, the modulus of these materials and their slow degradation may not be favourable for soft tissue engineering. In comparison, hydrogels provide a more natural environment for soft tissue formation, but generally have poor mechanical strength and shape persistence. 
Thus, hydrogel scaffolds with good mechanical integrity and tunable degradation rates are very appealing. Whilst scaffolds could potentially be loaded with cells (e.g., adipocytes, preadipocytes, adipose-derived stem cells) before implantation [23,25,28-31,34,35], a lack of nutrient and oxygen supply to the implanted cells prior to tissue ingrowth and angiogenesis are major concerns that would result in a loss of viability, particularly for large constructs. An alternative is to implant porous scaffolds that promote tissue infiltration and growth from the host, although formation of adipose rich tissue is particularly difficult. Nevertheless, the formation of well vascularised connective tissue throughout the scaffold would provide a suitable environment for subsequent injection of autologous fat grafts, and provide structural support for the maturing tissue construct [24,25]. Regardless of the approach that is employed, the ability to tailor the mechanical properties and biodegradation rate of scaffolds are important parameters for tissue augmentation and breast reconstruction.

Previously we fabricated highly porous and robust PEG-based sponges that showed excellent tissue responses in vivo [36]. In this case, the highly interconnected pores were generated from gas bubbles that formed due to the acid chloride/alcohol reaction used in the preparation [36]. Although this is a convenient method to introduce porosity, direct and simultaneous control over the pore size, degradation rate and mechanical properties of the sponges was difficult to achieve. Therefore, this study describes the fabrication and evaluation of porous polyester-ether hydrogels (PEH) produced via similar acid chloride/alcohol chemistry, but with significantly improved scope to control the scaffolds properties. The PEHs were prepared directly from commercially available reagents via a cost-effective, facile, and scalable manufacturing process. Furthermore, we demonstrate that the choice of cross-linker and the incorporation of a hydrophobic modifier facilitates the manufacture of hydrogels with tunable swelling, mechanical and degradation characteristics, leading to PEHs with excellent mechanical integrity under compression. In combination, these parameters provide the means to adjust the properties of the hydrogels, allowing for tissue-specific adaptation. In vivo, the PEHs display high tissue permeability and vascularization, fast biodegradation, good biocompatibility and minimal inflammatory response. The tunable properties and favourable tissue interactions of the PEHs make them promising candidates for tissue engineering applications.

\section{Experimental Section}

\subsection{Materials}

All reagents were used as received unless otherwise stated. Pentaerythritol ethoxylate (PE; $M_{n}$ $\sim 800 \mathrm{Da})$, poly(ethylene glycol) ( $\left.\mathrm{PEG}_{600} ; M_{\mathrm{n}} \sim 600 \mathrm{Da}\right), \varepsilon$-caprolactone $(97 \%)$, sebacoyl chloride ( $\geq 95 \%)$, succinyl chloride (95\%), 1,3,5-benzene tricarbonyltrichloride (trimesoyl chloride) $(98 \%)$, trans-2-[3-(4-tert-butylphenyl)-2-methyl-2-propenylidene]malononitrile (DCTB) ( $\geq 99.0 \%)$, stannous octoate $(92.5-100 \%), 2,2^{\prime}$-dithiodiethanol (90\%), sodium trifluoroacetate (NaTFA) $(99.999 \%)$ and phosphate buffered saline (PBS) tablets were purchased from Sigma-Aldrich (St. Louis, MO, USA). Gibco $^{\text {TM }}$ Dulbecco's Modified Eagle Medium (DMEM), L-glutamine, trypsin-EDTA (0.05\%), trypan blue (0.4\%), Fetal Bovine Serum (FBS) and penicillin-streptomycin were obtained from Thermo Fisher Scientific (Waltham, MA, USA). DMEM was supplemented with $10 \% v / v$ FBS, $1 \% v / v$ L-glutamine and $1 \% v / v$ penicillin-streptomycin prior to use for the cell viability assays. Dichloromethane ( $\geq 99.5 \%)$, tetrahydrofuran (THF) (Honeywell, Morris Plains, NJ, USA, 99.99\%), ethanol (undenatured 100\%), sodium carbonate $(\geq 99.2 \%$, anhydrous), sodium chloride $(\geq 99 \%)$ and toluene $(\geq 99.5 \%)$ were purchased from Chem-Supply (Adelaide, Australia). CelltiterAqueousOne solution for cell viability assays was obtained from Promega (Madison, WI, USA). Anti-CD68 antibody (ED1) antibody was purchased from AbD Serotec, Oxford, UK.

\subsection{Instrumentation}

Enviro-scanning electron microscopy (E-SEM) was conducted on a FEI Quanta FEG 200 Enviro-SEM (Thermo Scientific, Waltham, MA, USA). Samples were mounted on carbon tabs. 
Mechanical testing was carried out using an Instron Microtester 5848 (Instron, Norwood, MA, USA) equipped with Bluehill material testing software. Matrix-assisted laser desorption ionisation time-of-flight mass spectrometry (MALDI ToF MS) was performed on a Bruker Autoflex III mass spectrometer (Bruker Daltonics, Bremen, Germany) operating in positive/linear mode. DCTB and NaTFA were dissolved in THF (10 mg/mL and $1 \mathrm{mg} / \mathrm{mL}$, respectively) and then mixed with the polymer $(1 \mathrm{mg} / \mathrm{mL}$ in THF) in a ratio of 10:1:1. An aliquot of this solution $(0.3 \mu \mathrm{L})$ was spotted onto a ground steel target plate and the solvent allowed to evaporate. FlexAnalysis (Bruker, Bremen, Germany, version 2.2) was used to analyse the data. ${ }^{1} \mathrm{H}$ NMR spectroscopy was performed on a Varian Unity400 (400 MHz) spectrometer (Agilent, Santa Clara, CA, USA), using the solvent as lock.

\subsection{Fused Salt Template Preparation}

A mortar and pestle was used to grind crystalline sodium chloride $(\mathrm{NaCl})$, which was then sieved (Endecotts Ltd. (London, UK) set of standard laboratory test sieves) to obtain 300-600 $\mu \mathrm{m}$ sized salt particles. The salt particles $(4 \mathrm{~g})$ were transferred into polyethylene vials $(28 \mathrm{~mL})$ and were compressed gently with a cylindrical metal compressor. The vials were then transferred into a humidifier and maintained at room temperature ( $80 \%$ humidity) for $24 \mathrm{~h}$ to produce the fused salt templates. The fused templates were then dried in vacuo for $18 \mathrm{~h}\left(100{ }^{\circ} \mathrm{C}, 20 \mathrm{mbar}\right)$, capped and placed in a desiccator until further use.

\subsection{Synthesis of $\alpha, \omega$-Dihydroxyl Poly(Caprolactone) (PCL)}

2,2'-Dithiodiethanol (1.08 g, $7.00 \mathrm{mmoL}), \varepsilon$-caprolactone ( $20.0 \mathrm{~g}, 175 \mathrm{mmoL})$ and stannous octoate $(0.95 \mathrm{~g}, 2.34 \mathrm{mmoL})$ were dissolved in anhydrous toluene $(45 \mathrm{~mL})$ under argon and heated at $110{ }^{\circ} \mathrm{C}$ for $24 \mathrm{~h}$. After cooling to room temperature, the mixture was diluted with THF $(50 \mathrm{~mL})$ and precipitated into cold methanol $\left(-18^{\circ} \mathrm{C}, 1 \mathrm{~L}\right)$. The precipitate was collected by filtration and dried in vacuo $(0.1 \mathrm{mbar})$ to afford $\alpha, \omega$-dihydroxyl PCL as a white powder, $18.8 \mathrm{~g}(94 \%): M_{\mathrm{n}}(\mathrm{NMR})=3.2 \mathrm{kDa} ; M_{\mathrm{n}}$ (MALDI ToF $\mathrm{MS})=3.3 \mathrm{kDa}$, Polydispersity index $(\mathrm{PDI})=1.07$

\subsection{Preparation of Polyester-Ether Hydrogels (PEHs)}

PEG $_{600}(0.75 \mathrm{~g}, 1.26 \mathrm{mmoL}), \mathrm{PE}(0.50 \mathrm{~g}, 0.63 \mathrm{mmoL})$, and various amounts of dihydroxyl PCL (0 wt \%, $2 \mathrm{wt} \%$, or $5 \mathrm{wt} \%$ ) were dissolved in dichloromethane (DCM, 10\% v/v) (Table 1). Subsequently sebacoyl chloride (SebCl) $(0.60 \mathrm{~g}, 2.51 \mathrm{mmoL})$, succinyl chloride (SucCl) $(0.39 \mathrm{~g}$, $2.51 \mathrm{mmoL})$, or trimesoyl chloride $(\mathrm{TmsCl})(1.27 \mathrm{~g}, 4.77 \mathrm{mmoL})$ was added. The precursors were vortexed for $10 \mathrm{~s}$ and $1.2 \mathrm{~mL}$ of this solution was immediately pipetted into the vial containing the fused salt template and centrifuged for $30 \mathrm{~s}(4.4 \mathrm{krpm})$. The vial was then placed into an oven at $60^{\circ} \mathrm{C}$ for $1 \mathrm{~h}$. The cross-linked gel was removed from the vial and placed in $30 \mathrm{mM}$ sodium carbonate solution $(100 \mathrm{~mL} / \mathrm{gel})$. The solution was changed every $30 \mathrm{~min}$ for $2 \mathrm{~h}$ and then every hour for $3 \mathrm{~h}$ before a final exchange for $24 \mathrm{~h}$. The resulting PEHs were then stored in PBS prior to characterisation. PEHs produced with succinyl chloride, sebacoyl chloride and trimesoyl chloride are referred to as Suc- $\mathrm{PEH}_{\# \text {, }}$ Seb-PEH and $\mathrm{Tm}_{\mathrm{S}}-\mathrm{PEH}_{\#}$, respectively, whereby the subscript refers to the weight percentage (wt \%) of the dihydroxyl PCL used. 
Table 1. Reagent quantities for the preparation of Suc-PEHs, Seb-PEHs, and Tms-PEHs.

\begin{tabular}{cccc}
\hline Reagent & Suc-PEH $_{\#}$ & Seb-PEH & Tms-PEH\# \\
\hline PE & $0.50 \mathrm{~g}, 0.63 \mathrm{mmoL}$ & $0.50 \mathrm{~g}, 0.63 \mathrm{mmoL}$ & $0.50 \mathrm{~g}, 0.63 \mathrm{mmoL}$ \\
PEG 600 & $0.75 \mathrm{~g}, 1.26 \mathrm{mmoL}$ & $0.75 \mathrm{~g}, 1.26 \mathrm{mmoL}$ & $0.75 \mathrm{~g}, 1.26 \mathrm{mmoL}$ \\
Dihydroxyl PCL & $0 \mathrm{mg}, 33 \mathrm{mg}, 82 \mathrm{mg}$ & $0 \mathrm{mg}, 37 \mathrm{mg}, 93 \mathrm{mg}$ & $0 \mathrm{mg}, 38 \mathrm{mg}, 96 \mathrm{mg}$ \\
$(0 \mathrm{wt} \%, 2 \mathrm{wt} \%, 5 \mathrm{wt} \%)$ & $151 \mu \mathrm{L}$ & $180 \mu \mathrm{L}$ & $170 \mu \mathrm{L}$ \\
DCM $(10 \% v / v)$ & $0.39 \mathrm{~g}, 2.51 \mathrm{mmoL}$ & - & - \\
SucCl & - & $0.60 \mathrm{~g}, 2.51 \mathrm{mmol}$ & - \\
SebCl & - & - & $0.67 \mathrm{~g}, 2.51 \mathrm{mmoL}$ \\
TmsCl & &
\end{tabular}

\subsection{Swelling Studies}

Dehydrated PEHs $\left(1 \mathrm{~cm}^{3}\right)$ were weighed and subsequently placed in Milli-Q water for $48 \mathrm{~h}$. The percentage equilibrium solvent ratio (\%ESR) was calculated using the equation: \%ESR $=\left(\left(W_{\mathrm{s}}-W_{\mathrm{d}}\right) / W_{\mathrm{d}}\right) \times 100 \%$, where $W_{\mathrm{s}}$ and $W_{\mathrm{d}}$ refer to the swollen and dried weights, respectively. The analysis was conducted in triplicate and the results averaged.

\subsection{Pore Size Analysis Via E-SEM}

PEHs (2 wt \% PCL) swollen in PBS for $48 \mathrm{~h}$ were cut in half and mounted on a carbon tab. The exposed internal surfaces were analysed using E-SEM under low vacuum conditions to observe the porous structure of the hydrogels. ImageJ software (v1.48k, National Institute of Health, Bethesda, MD, USA) was utilised to determine the average pore sizes.

\subsection{Compressive Evaluation of PEHs}

Swollen PEHs were cut into cubes $\left(1 \mathrm{~cm}^{3}\right)$ prior to compressive testing. The PEHs were not subjected to stress preconditioning prior to compressive evaluation. The scaffolds were placed between the metal plates of an Instron Microtester 5848 (with $50 \mathrm{~N}$ load cell) and were subjected to compression up to $80 \%$ strain. The resulting stress versus strain profiles were used in determination of the compressive moduli of the PEHs. Some PEHs were also subjected to cyclic compression up to $80 \%$ strain to study their elastic properties.

\subsection{In Vitro Degradation Study}

PEHs (2 wt \% PCL) synthesised with the three cross-linkers, were cut into cubes $\left(5 \mathrm{~mm}^{3}\right)$, dehydrated in ethanol and dried overnight in a vacuum oven $\left(60^{\circ} \mathrm{C}\right)$. Dried samples were weighed and placed into PBS ( $20 \mathrm{~mL}, 0.01 \% w / v$ sodium azide). The vials were capped and transferred to an orbital shaker $\left(37^{\circ} \mathrm{C}, 100 \mathrm{rpm}\right)$. Three samples were removed from the orbital shaker at each time point $(1,2,4$ and 8 weeks $)$ and soaked in deionised water for $30 \mathrm{~min}(3 \times 20 \mathrm{~mL})$. Subsequently, the hydrogels were dehydrated by soaking in ethanol for $1 \mathrm{~h}(2 \times 20 \mathrm{~mL})$ followed by drying in vacuo $\left(60^{\circ} \mathrm{C}, 24 \mathrm{~h}\right)$. The dried samples were then weighed and the mass values obtained were plotted against time to obtain the degradation profiles.

\subsection{In Vitro Cytotoxicity Evaluation}

For the cytotoxicity evaluation, we used a previously described method [36]. Briefly, dehydrated PEHs (100 mg) were sterilised ( $80 \% v / v$ ethanol solution; $30 \mathrm{~min}$ ), washed and incubated in DMEM $\left(37^{\circ} \mathrm{C}, 72 \mathrm{~h}\right)$. The hydrogels were removed and the conditioned media was used in the cell viability assay. To determine the cytotoxicity of hydrogel degradation products, PEHs $(500 \mathrm{mg})$ were degraded $(1 \mathrm{M} \mathrm{HCl}, 5 \mathrm{~mL})$ and the degradation products isolated via azeotropic distillation with water. For cytotoxicity studies the degradation products $(100 \mathrm{mg})$ were dispersed in sterile DMEM, sterilised (UV; $30 \mathrm{~min}$ ), and then filtered $(0.22 \mu \mathrm{m})$. 
Confluent National Institute of Health (NIH) 3T3-L1 cells were trypsinised, diluted $\left(1.25 \times 10^{5}\right.$ cells $\left./ \mathrm{mL}\right)$ and transferred to 96 well plates $(80 \mu \mathrm{L} /$ well $)$. The plates were placed in the incubator for $4 \mathrm{~h}, \mathrm{PEH}$ conditioned media or degradation products were added, and the plates were returned to the incubator $(72 \mathrm{~h})$. CelltiterAqueousOne Solution was added $(20 \mu \mathrm{L} /$ well $)$ and after $2 \mathrm{~h}$ in the incubator the UV/Vis absorbance was recorded at 490 and $700 \mathrm{~nm}$ (for background absorbance subtraction) using a Cary 50 Bio UV-Visible Spectrophotometer (Varian, Mulgrave, Australia).

\subsection{In Vivo Implantation Study}

The study was conducted in accordance with relevant national legislation on the use of animals for research. All procedures were conducted according to the guidelines of the National Health and Medical Research Council (NHMRC) of Australia and were approved by the Animal Ethics Committee, St Vincent's Hospital, Melbourne (ID: 017/10).

Seb- $\mathrm{PEH}_{2}$ disks (diameter $=10 \mathrm{~mm}$, height $=4 \mathrm{~mm}$ ) were placed into plastic vials and doubly sealed in zip-lock bags prior to gamma irradiation. Gamma sterilisation was carried out at Steritech, Victoria, Australia (25 kGy minimum). Following sterilisation, the hydrogels were placed in sterile PBS for $3 \mathrm{~h}$ prior to implantation. The PEHs were implanted into 12 rats for 3 time points using a previously documented procedure [36], noting that for surgery, animals were anaesthetised and maintained in an anaesthetised state using isoflurane, and histology sections were stained with ED1 for detection of macrophages and foreign body giant cells.

\section{Results and Discussion}

\subsection{Preparation of PEHs}

The porous polyester-ether hydrogels (PEHs) were fabricated via a facile approach using acid chloride chemistry [36,37], whereby pentaerythritol ethoxylate (PE) and linear poly(ethylene glycol) $\left(\mathrm{PEG}_{600}\right)$ were cross-linked with either sebacoyl chloride (SebCl), succinyl chloride (SucCl) or trimesoyl chloride $(\mathrm{TmsCl})$. The precursors were dissolved in dichloromethane, combined with various amounts of $\alpha, \omega$-dihydroxyl poly(caprolactone) (PCL), and then allowed to gel in the presence of fused salt-templates (Figure 1). PE, a low molecular weight star polymer composed of four PEG arms, and $\mathrm{PEG}_{600}\left(M_{\mathrm{n}} \sim 600 \mathrm{Da}\right)$ are inexpensive and commercially available hydroxyl-terminated PEG derivatives. $\mathrm{PEG}_{600}$ was used to decrease the cross-linking density and stiffness of the hydrogels, as well as to slow down the cross-linking reaction so that the hydrogel precursor mixture could easy infiltrate into the template pores prior to gelation. $\mathrm{SebCl}$ and $\mathrm{SucCl}$ are diacid chlorides derived from naturally occurring carboxylic acids, whereas $\mathrm{TmsCl}$ is a triacid chloride derivative of benzene tricarboxylic acid. The cross-linking reaction between the acid chloride groups of $\mathrm{SebCl}, \mathrm{SucCl}, \mathrm{TmsCl}$, and the hydroxyl end-groups of the PEG derivatives leads to the formation of an ester bonded network and the release of $\mathrm{HCl}$, which is neutralised in subsequent washing steps. For all of the PEHs, the PE: acid chloride: $\mathrm{PEG}_{600}$ mole ratio was kept constant at 1:4:2 in order to provide the same theoretical cross-linking density for all of the hydrogels. This theoretically provides a completely cross-linked network for PEHs prepared with $\mathrm{SebCl}$ and SucCl. In the case of the triacid chloride $\mathrm{TmsCl}$ there is an excess of acid-chloride groups that during the aqueous washing steps would be hydrolysed to carboxylic acids and could potentially be used for the conjugation of bioactive molecules to modulate cell behaviour as required.

Previously, we have demonstrated that the mechanical properties of PEG-based hydrogels can be improved through the covalent incorporation of PCL $[11,37]$. Therefore, telechelic dihydroxyl PCL was cross-linked within the hydrogel network (Figure 1). To produce an interconnected porous structure that would allow the penetration of cells and vascularisation within the hydrogels, sacrificial fused sodium chloride templates (particle size 300-600 $\mu \mathrm{m}$ ) were used. Fused salt templates were prepared by packing pre-sieved salt particles into a vial followed by exposure to a humid environment, which causes the salt particles to fuse together at points of contact. This approach ensures that the pores of 
the resulting hydrogels are interconnected allowing the template to be easy dissolved and washed away, and for tissue to penetrate throughout the scaffold. Following cross-linking, the PEHs were subsequently immersed in a solution of sodium carbonate to neutralise any $\mathrm{HCl}$ that may be trapped within. The hydrogels were referred to as $\mathrm{X}-\mathrm{PEH}_{\#}$, whereby the prefix denotes the cross-linker and the subscript denotes the wt \% of PCL used to prepare the PEHs (e.g., Suc- $\mathrm{PEH}_{2}$ refers to a succinyl chloride cross-linked hydrogel with 2 wt \% PCL).

\subsection{Swelling Characteristics of PEHs}

To determine the effect of the cross-linker, and PCL content on swelling properties, the mass of the fully swollen and dried PEHs were obtained and used to calculate the percentage equilibrium swelling ratios (\%ESRs) (Table 2). Out of all the PEHs prepared, Suc-PEHs clearly displayed much higher \%ESRs. The longer alkyl backbone and the benzene ring of the ester cross-links generated from using $\mathrm{SebCl}$ and $\mathrm{TmsCl}$, respectively, as well as higher molecular weight of the cross-linkers, create a more hydrophobic environment within Seb-PEHs and Tms-PEHs as compared to Suc-PEHs, and hence reduce the water absorbing capabilities of the $\mathrm{PEH}$. SucCl has a shorter alkyl backbone and hence the resulting PEHs are more hydrophilic and absorb more water. 


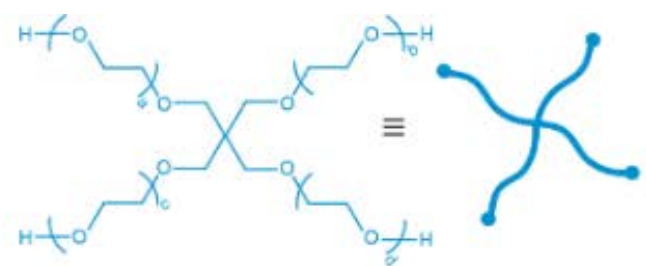

Pentaerythritol Ethoxylate (PE)

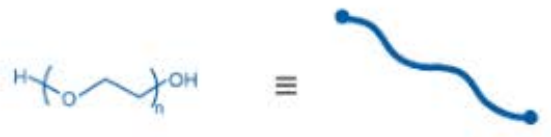

Poly(ethylene glycol) (PEG600)

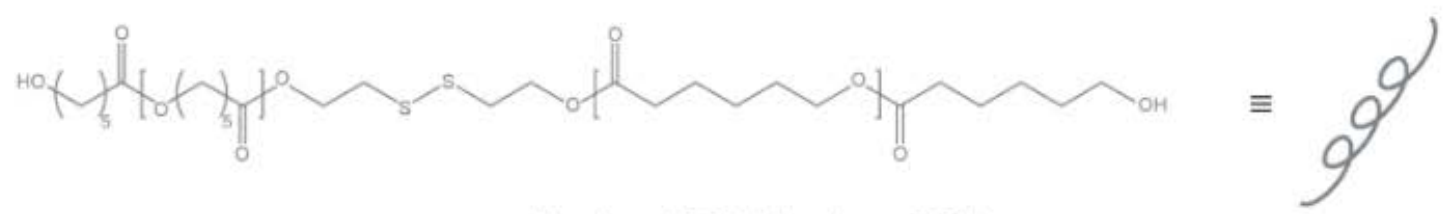

a, w-dihydroxyl PCL (dihydroxy-PCL)
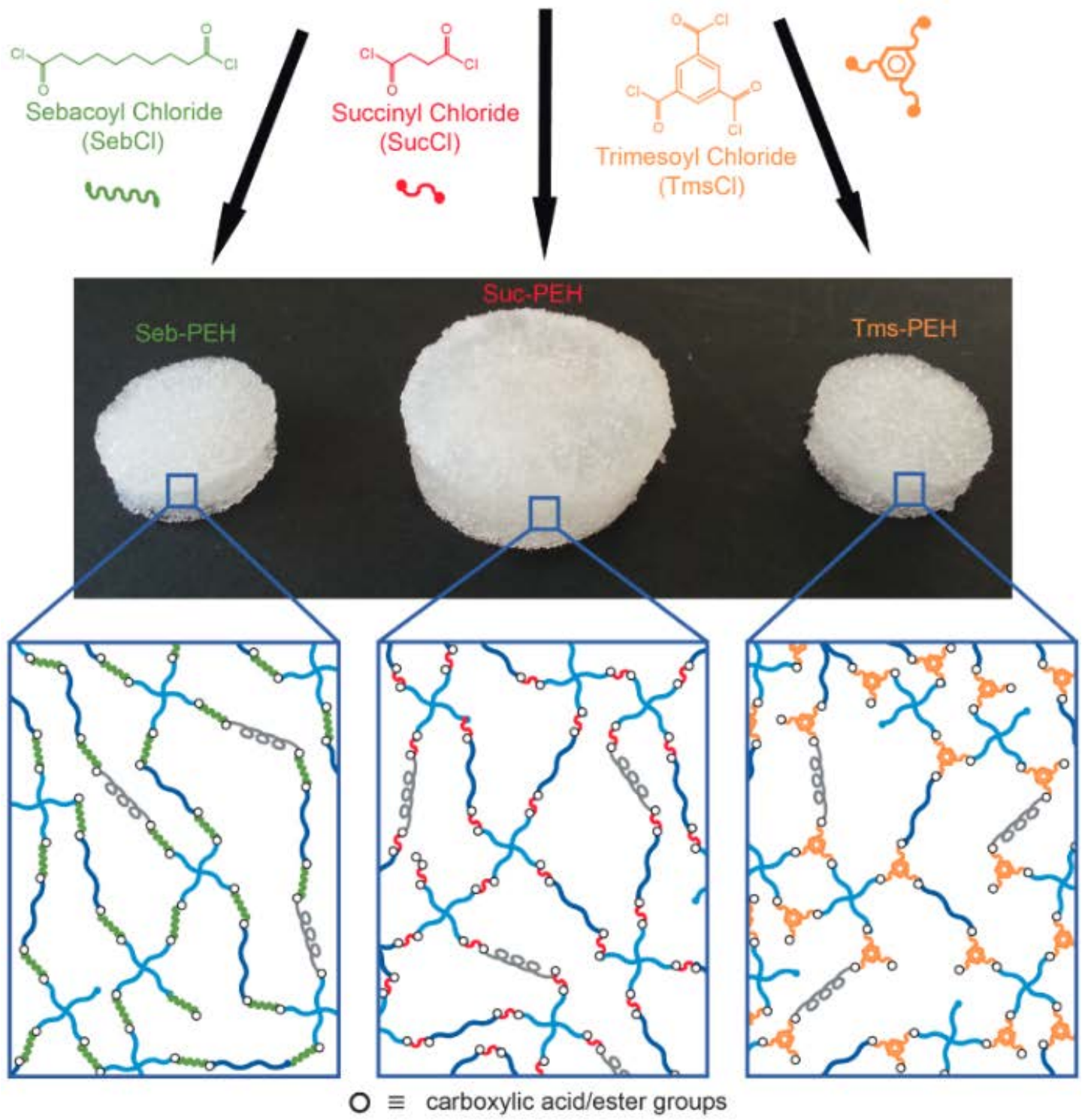

Figure 1. Synthesis of Suc- $\mathrm{PEH}_{\#}$, Seb-PEH , and Tms-PEH and their representative network structures. 
Table 2. Percentage equilibrium swelling ratio (\%ESR), weight percentage of hydrophobic content, average pore size and mechanical characteristics (under compression testing) for the PEHs.

\begin{tabular}{|c|c|c|c|c|c|c|}
\hline $\mathrm{PEH}^{\mathrm{a}}$ & $\%$ ESR & $\begin{array}{c}\text { Hydrophobic } \\
\text { Content (wt \%) }\end{array}$ & $\begin{array}{l}\text { Average Pore } \\
\text { Size }(\mu \mathrm{m})\end{array}$ & $\begin{array}{c}\text { Ultimate } \\
\text { Stress (MPa) }\end{array}$ & $\begin{array}{c}\text { Ultimate } \\
\text { Compression (\%) }\end{array}$ & $\begin{array}{c}\text { Compressive } \\
\text { Modulus (KPa) }\end{array}$ \\
\hline Suc-PEH & $1209 \pm 65$ & 24 & - & $33 \pm 3.4$ & $46 \pm 2.0$ & $81.0 \pm 11$ \\
\hline Suc- $P E H_{2}$ & $1184 \pm 56$ & 25 & $456 \pm 114$ & $51 \pm 5.3$ & $58 \pm 2.1$ & $89.0 \pm 0.1$ \\
\hline Suc-PEH & $1139 \pm 52$ & 27 & - & $63 \pm 4.2$ & $75 \pm 4.1$ & $81.0 \pm 10$ \\
\hline Seb-PEH & $327 \pm 4.5$ & 32 & - & $-^{c}$ & $-^{c}$ & $183 \pm 28$ \\
\hline $\mathrm{Seb}-\mathrm{PEH} \mathrm{H}_{2}$ & $310 \pm 2.1$ & 34 & $467 \pm 118$ & $-{ }^{c}$ & $-{ }^{c}$ & $250 \pm 20$ \\
\hline Seb-PEH & $301 \pm 2.3$ & 36 & - & $-c$ & $-c$ & $330 \pm 5.7$ \\
\hline Tms-PEH & $370 \pm 6.3$ & 35 & - & $124 \pm 18$ & $60 \pm 9.2$ & $192 \pm 6.0$ \\
\hline Tms-PEH & $340 \pm 0.9$ & 35 & $477 \pm 102$ & $-^{c}$ & $-c$ & $148 \pm 3.0$ \\
\hline Tms-PEH & $321 \pm 5.5$ & 38 & - & $-{ }^{c}$ & $-{ }^{c}$ & $193 \pm 6.0$ \\
\hline
\end{tabular}

As the PCL content in the PEHs was increased from $0 \mathrm{wt} \%$ to $5 \mathrm{wt} \%$ there was a reduction in the $\% \mathrm{ESR}$, which correlated with the overall increase in the hydrophobic content wt \% (Table 2). This is consistent with the effects of hydrophobicity observed for PEHs prepared using $\mathrm{SebCl}$ and $\mathrm{TmsCl}$ cross-linkers. The effect of hydrophobic components on the repulsion of water and its subsequent effects on hydrogel swelling are also supported by other studies [38].

\subsection{Evaluation of Porous Structure}

Enviro-scanning electron microscopy (ESEM) was carried out on X-PEH ${ }_{2}$, swollen in Milli-Q water, to determine their porous structure and the average pore size (Table 2). ESEM revealed that the pore sizes observed within the PEHs correlate well with the size of the salt particles (300-600 $\mu \mathrm{m})$ used in the templates and were interconnected as a result of the fusing process (Figure 2). Murphy et al. has demonstrated that fusing salt particles under humid conditions leads to improved interconnectivity of the final pores [39]. The average pore sizes calculated for Suc- $\mathrm{PEH}_{2}$, Seb- $\mathrm{PEH}_{2}$, and Tms- $\mathrm{PEH}_{2}$ were 456,467 and $477 \mu \mathrm{m}$, respectively (Table 2), which fall within the middle of the range of the salt particles. The large size and interconnected nature of the pores are anticipated to facilitate rapid tissue penetration and vascularisation as well as facile nutrient and fluid transport.

Regarding the salt-templating technique, it is possible to control the pore size of the hydrogels since the porogen particle size can be directly tailored to a specific range [40]. Importantly, this allows potential targeting of specific tissue types, as recent studies have demonstrated that certain pore sizes are better suited for the regeneration of specific tissues, including bone, skin and adipose tissue [41-43].

\subsection{Mechanical Evaluation}

Tissue engineering scaffolds need to maintain a 3D environment and possess suitable mechanical properties to shield the growing tissue from external forces $[3,24]$. Therefore, the robustness of the swollen PEHs was investigated via compressive testing with respect to the dihydroxyl PCL content and the type of cross-linker (Table 2).

Surprisingly, Seb-PEHs, Tms- $\mathrm{PEH}_{2}$, and Tms- $\mathrm{PEH}_{5}$ were found to be highly elastic, maintaining their structural integrity even after compressive strains of $80 \%$. For example, cyclic testing of Seb-PEH demonstrated that the hydrogel remained elastic without fracture even after 15 compression cycles up to $80 \%$ (Figure 3). The compressive moduli of the Seb-PEHs increased with increasing PCL content (Table 2), which is consistent with our previous studies [11,36]. The Tms-PEHs did not initially possess the highly elastic nature of the Seb-PEHs until the incorporation of PCL. Following PCL incorporation, the Tms-PEHs also maintained an elastic structure with increasing compressive moduli with increasing PCL content (Table 2). The \% compressive strain of the Suc-PEHs varied between $46 \%$ to $75 \%$, and increased with increasing PCL content, along with the ultimate stress (Table 2). 
However, the compressive moduli of the Suc-PEHs remained approximately constant regardless of the PCL content.
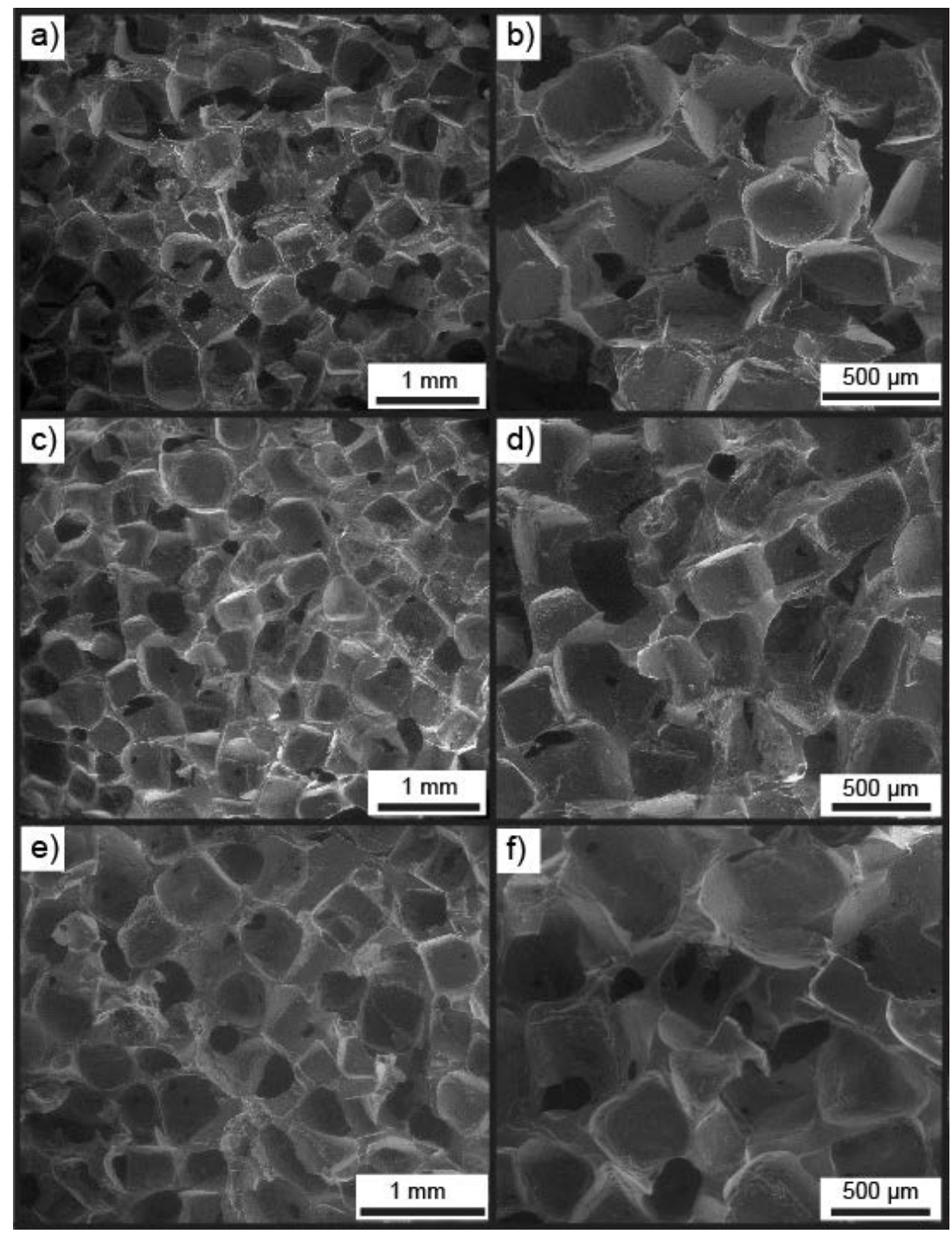

Figure 2. Enviro-SEM images of (a,b) Suc-PEH ${ }_{2},(\mathbf{c}, \mathbf{d})$ Seb-PEH 2 and $(\mathbf{e}, \mathbf{f}) \mathrm{Tms}^{\mathrm{T}}-\mathrm{PEH}_{2}$.

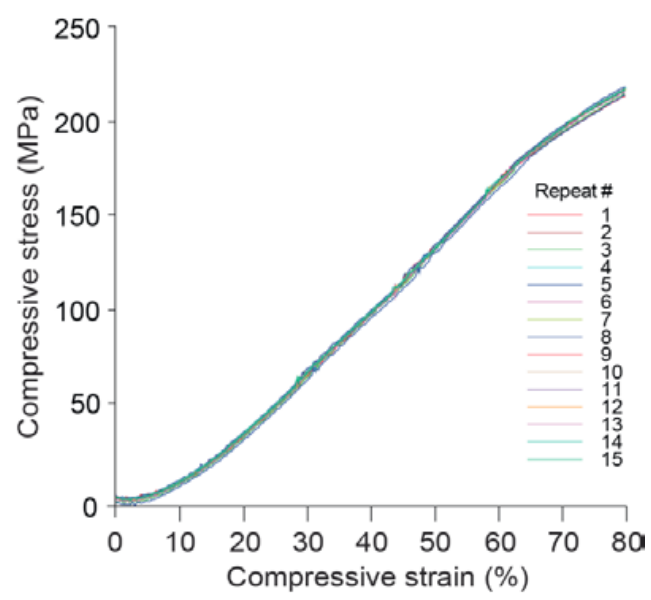

Figure 3. Compressive stress vs strain profile for Seb- $\mathrm{PEH}_{2}$ over 15 compression cycles. 
The observed trends in the swelling of the PEHs with differing hydrophobicity could be responsible for the different compressive behaviours observed. As the Suc-PEHs possess a much higher $\%$ ESR, the polymer chains within the cross-linked network are extended and stretched, reducing their capacity to deform under compressive stress, and increasing the probability of fracture. Conversely, the Seb-PEHs and Tms-PEHs swell to a much lower degree as a result of the more hydrophobic cross-links, preventing the polymer chains from extending completely. Therefore, the Seb-PEHs and Tms-PEHs are more deformable under compressive stress, resulting in elastic behaviour even at high compressive strains. The lower elasticity observed for Tms- $\mathrm{PEH}_{0}$, as compared to the Seb-PEHs, is likely to result from the rigid benzoate ester cross-links as compared to the flexible alkyl esters of the latter. The incorporation of long deformable PCL chains into Tms- $\mathrm{PEH}_{2}$ and Tms- $\mathrm{PEH}_{5}$ leads to an overall increase in hydrophobicity and reduction in swelling, leading to an improvement in the elasticity.

These results demonstrate that by using different cross-linkers and varying the PCL content, the compressive properties of the PEHs can be tuned. Tuning the mechanical properties of the scaffold to match the target tissue allows improved tissue responses, especially for mechanosensitive tissue [44]. In the case of the PEHs, similar moduli are observed for tissues such as skin, kidney, and liver $[45,46]$ thus providing access to tailored mechanical properties for specific tissues and applications.

\subsection{Degradation In Vitro}

Tissue engineering scaffolds that degrade in a controlled manner, allowing uniform tissue formation as cells regenerate within the porous structure of the scaffold are highly desirable. The advantage of the PEH system is the high density of ester cross-links, which makes them particularly susceptible to hydrolytic and enzymatic cleavage $[47,48]$. To determine the effect of the cross-linkers on the degradation rate, the Suc- $\mathrm{PEH}_{2}$, Seb- $\mathrm{PEH}_{2}$, and Tms- $\mathrm{PEH}_{2}$ were stored in PBS solution for 8 weeks at $37^{\circ} \mathrm{C}$ and the mass loss was calculated at 1,2, 4 and 8 weeks. The degradation study revealed a mass loss of $\sim 35 \%-40 \%$ in 8 weeks for Tms-PEHs and Seb-PEHs, whereas the Suc-PEHs had completely degraded by 4 weeks (Figure 4a).

The hydrophobic cross-linkers in Seb-PEH and Tms-PEH with their long alkyl backbone (eight aliphatic carbons) and aromatic structure, respectively, are able to repel the water away from the ester cross-links more effectively than the short alkyl backbone (two aliphatic carbons) of the Suc-PEH cross-linker. Therefore, the latter is more susceptible to hydrolysis and degrades much quicker. Since the cross-linkers result in different degradation rates, this provides the possibility of utilising these three cross-linkers in combination for tuning of the degradation rates (and mechanical properties) as required. The degradation profiles obtained from this study are only representative of in vitro conditions and these rates could be further accelerated by the presence of hydrolytic enzymes in vivo. The results of the in vitro degradation study demonstrate the potential of the PEHs as biodegradable implants. A degradable implant would allow the tissue to regenerate to form a uniform structure and prevent foreign material from interfering with tissue function.

\subsection{In Vitro Cell Viability}

As implantable scaffolds, the PEHs and their degradation products need to be non-toxic. Therefore, in vitro cytotoxicity studies were conducted with $3 \mathrm{~T} 3$ fibroblasts. The cells were incubated in the presence of PEH conditioned media at concentrations of 100 and $1000 \mathrm{ppm}$ for $72 \mathrm{~h}$. Regardless of the PEHs employed, minimal effect on cell viability was observed (Figure $4 \mathrm{~b}$ ). Subsequently, the cells were incubated for $72 \mathrm{~h}$ with various concentrations of PEH degradation products obtained from accelerated acid catalysed degradation. In the presence of $100 \mathrm{ppm}$ of the degradation products a significant increase in the metabolic activity of the cells was observed (Figure 4c). For $1000 \mathrm{ppm}$ of the degradation products a slight reduction in metabolic activity was observed, but relative to the control this was statistically insignificant $(p>0.05)$.

Complete hydrolytic degradation of the ester bonds in the PEHs theoretically affords low toxicity compounds, including PEG derivatives, sebacic acid, succinic acid, trimesic acid, and 
6-hydroxyhexanoic acid (from complete degradation of the PCL). PEG is considered to be non-toxic and is approved by the FDA for cosmetic and drug delivery applications [49-51]. Sebacic acid is an intermediate in fatty acid oxidation [52]. Succinic acid is also naturally present in cells and plays a significant role in the citric acid cycle [53]. Trimesic acid, a synthetic tricarboxylic acid, and 6-hydroxyhexanoic acid have high lethal dose $\left(\mathrm{LD}_{50}\right)$ values of 8.4 and $4.3 \mathrm{~g} / \mathrm{kg}$, respectively, which are unlikely to be reached through degradation of the scaffolds [54]. In vivo, degradation events are also likely to produce polymeric fragments that are cleared from the body. In particular, PCL degrades to low molecular weight fragments in vivo that can be completely excreted [55]. As the Seb-PEH 2 conditioned media and degradation products had minimal effect on the metabolic activity of cells in vitro, and Seb- $\mathrm{PEH}_{2}$ displayed excellent elastic properties, it was selected for further studies in vivo.
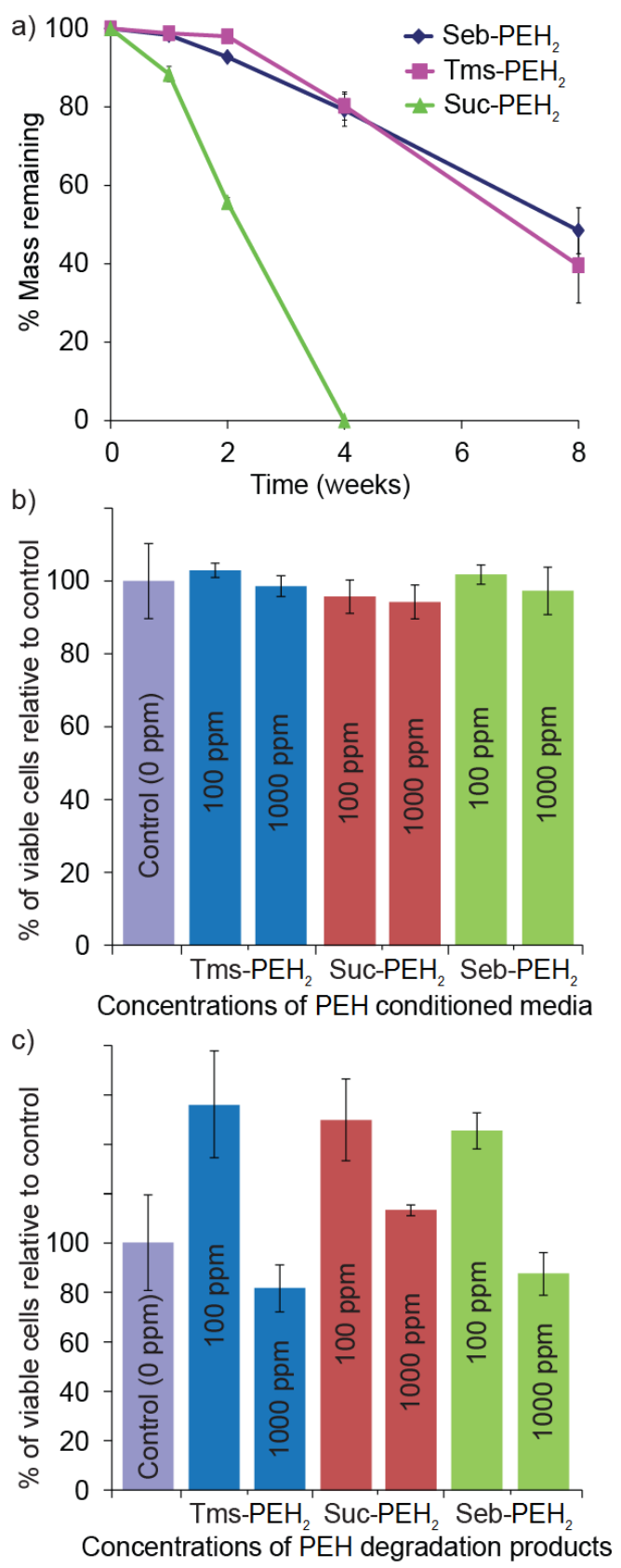

Figure 4. (a) In vitro degradation of $\mathrm{X}-\mathrm{PEH}_{2}$ over 8 weeks (PBS, $37^{\circ} \mathrm{C}$ ). Cytotoxicity evaluation of (b) $\mathrm{X}-\mathrm{PEH}_{2}$ conditioned media and (c) $\mathrm{X}-\mathrm{PEH}_{2}$ degradation products. 


\subsection{In Vivo Assessment}

To assess the biocompatibility, biodegradation, and immune response to the PEHs in vivo, as well as tissue in-growth and vascularisation, $\mathrm{Seb}-\mathrm{PEH}_{2}$ was implanted in rats [11,36]. Seb-PEH $\mathrm{CH}_{2}$ linders (10 mm diameter, $4 \mathrm{~mm}$ height) were implanted subcutaneously in the dorsal region of male Sprague-Dawley rats (Figure 5a-c), and subsequently removed after periods of 2, 8 and 16 weeks $(n=4$ for each time point). Removal of all of the PEHs was unremarkable without any macroscopic evidence of inflammation, toxicity or adverse effects in the surrounding tissue.

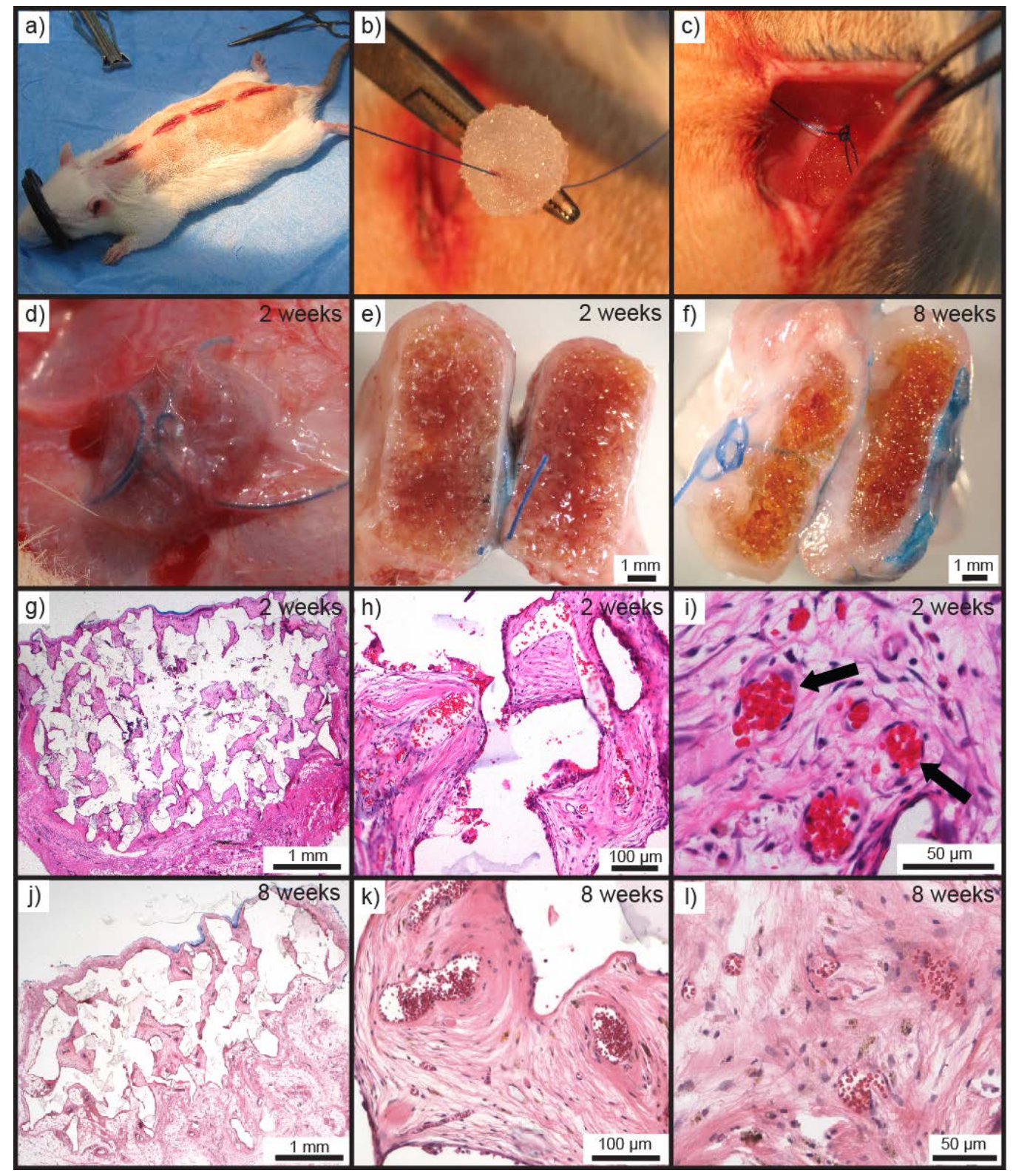

Figure 5. (a) Prepared subcutaneous pockets for implantation of Seb- $\mathrm{PEH}_{2}$. (b) Seb-PEH 2 cylinders prior to implantation and suturing. (c) Seb- $\mathrm{PEH}_{2}$ inserted and sutured into the dorsal pocket. (d) Seb-PEH 2 prior to removal at 2 weeks. Macroscopic cross-sections of Seb-PEH 2 explants at (e) 2 and (f) 8 weeks. H\&E stained sections of Seb-PEH 2 explants removed at 2 weeks at (g) $1.25 \times$, (h) $10 \times$, and (i) $20 \times$ magnification (note black arrows marking the central vasculature containing strongly eosinophilic red blood cells). H\&E stained sections of Seb-PEH 2 explants removed at 8 weeks at (j) $1.25 \times,(\mathbf{k}) 10 \times$, and (1) $20 \times$ magnification. 
Two week samples revealed that the PEHs were well integrated into the surrounding tissue (Figure 5d). Macroscopic observation of the hydrogels following bisection revealed that the hydrogels were intact and similarly sized to when implanted (Figure $5 \mathrm{e}$ ). The hydrogels were sectioned following fixing in paraffin and subsequently stained with H\&E to observe cellular infiltration (Figure $5 \mathrm{~g}-\mathrm{i}$ ). H\&E stained sections showed the penetration of dense cellular and highly vascularised tissue into the hydrogel from the surrounding tissue. Eosinophilic red blood cells within vasculature indicated vascularisation of the constructs (Figure 5h,i). Fragments of the PEHs could also be observed between the stained tissues indicating the location of the walls of the pores of the hydrogels (Figure $5 \mathrm{~g}, \mathrm{~h}$ ). The large gaps observed in the stained sections are likely to result from dehydration and shrinkage of the PEH pore walls and the tissue during processing into paraffin.

Bisection of the 8 week harvested tissue showed a slight decrease in thickness of the size of the explant and a yellowing of the hydrogel matrix. This reduction in size and yellowing could be indicative of degradative processes. Infiltration of tissue to the centre of the scaffolds was confirmed via H\&E staining, but a significant difference in the amount of penetrated tissue was not observed (Figure 5j). Although, it was noted that the tissue present after 8 weeks was of the loose-connective type, rather than the densely cellular tissue present at 2 weeks (Figure $5 \mathrm{k}, 1$ ). Vascularisation of scaffolds is crucial for the growth and survival of regenerating tissue [56,57]. Penetration of vascularised tissue to the centre of the hydrogels demonstrates the interconnected nature of the pores of the PEHs. The tissue developed within the PEH pores must have infiltrated from the surrounding tissue, since no cells were incorporated.

It was much more difficult to discern the implants in situ at 16 weeks compared to 2 and 8 weeks due to a marked reduction in height and greater integration into the underlying tissue. As per 2 and 8 weeks no macroscopic evidence of adverse effects was present in the tissue surrounding the anchoring suture, which was immediately dissected and processed for histology. Bisection of the harvested tissue revealed that the implants were much smaller in height and a very small amount of scaffold material was remaining (Figure 6a). H\&E staining was carried out to discern the tissue morphology and observe the presence of remaining scaffold material. Analysis of the sections revealed that by 16 weeks, there was a small amount of scaffold material remaining (Figure $6 b, c)$. Remnants were reduced in both size and number, and the tissue surrounding these was fibro-vascular tissue. This indicates that in 16 weeks the PEHs undergo major degradation, demonstrating their in vivo biodegradability.

As a response to both the tissue trauma of the implantation procedure and the presence of a hypoxic scaffold/tissue space, macrophages would be expected to be present in and around the implanted PEHs. As a means of determining macrophage and foreign body giant cell (FBGC) responses, ED1 immunostaining was carried out on all sections (Figure 6d-1) [58]. ED1 staining of 2 week samples revealed the presence of macrophages as expected. Macrophages were present mainly as well-dispersed cells within the penetrated tissue centrally within the scaffold pores, with only a few located at the tissue-hydrogel interface; in fact, the majority of cells at the interface were negative for ED1 labelling (Figure 6d-f).

Viewing of the 8 weeks sections showed that the macrophage response was clearly diminished when compared with the 2 week time point; they were smaller in size and less numerous (Figure $6 \mathrm{~g}-\mathrm{i}$ ). At the scaffold surface there were still minimal macrophage numbers and there was no tendency towards macrophage aggregation or FBGC formation, demonstrating the minimal response towards the hydrogel material. By 16 weeks the PEHs had undergone major degradation, as evidenced by the very small amount of scaffold and number of void spaces remaining in the sections. ED1-stained 16 weeks sections showed a very similar appearance with respect to macrophages and FBGCs to that seen at 8 weeks (Figure 6j-1). Analysis of the sections via ED1 staining clearly demonstrates that the PEHs initially resulted in a minor inflammatory response only and that this response diminished over the 16 week time course of the study, despite the continued presence of scaffold material and release of degradation products. 


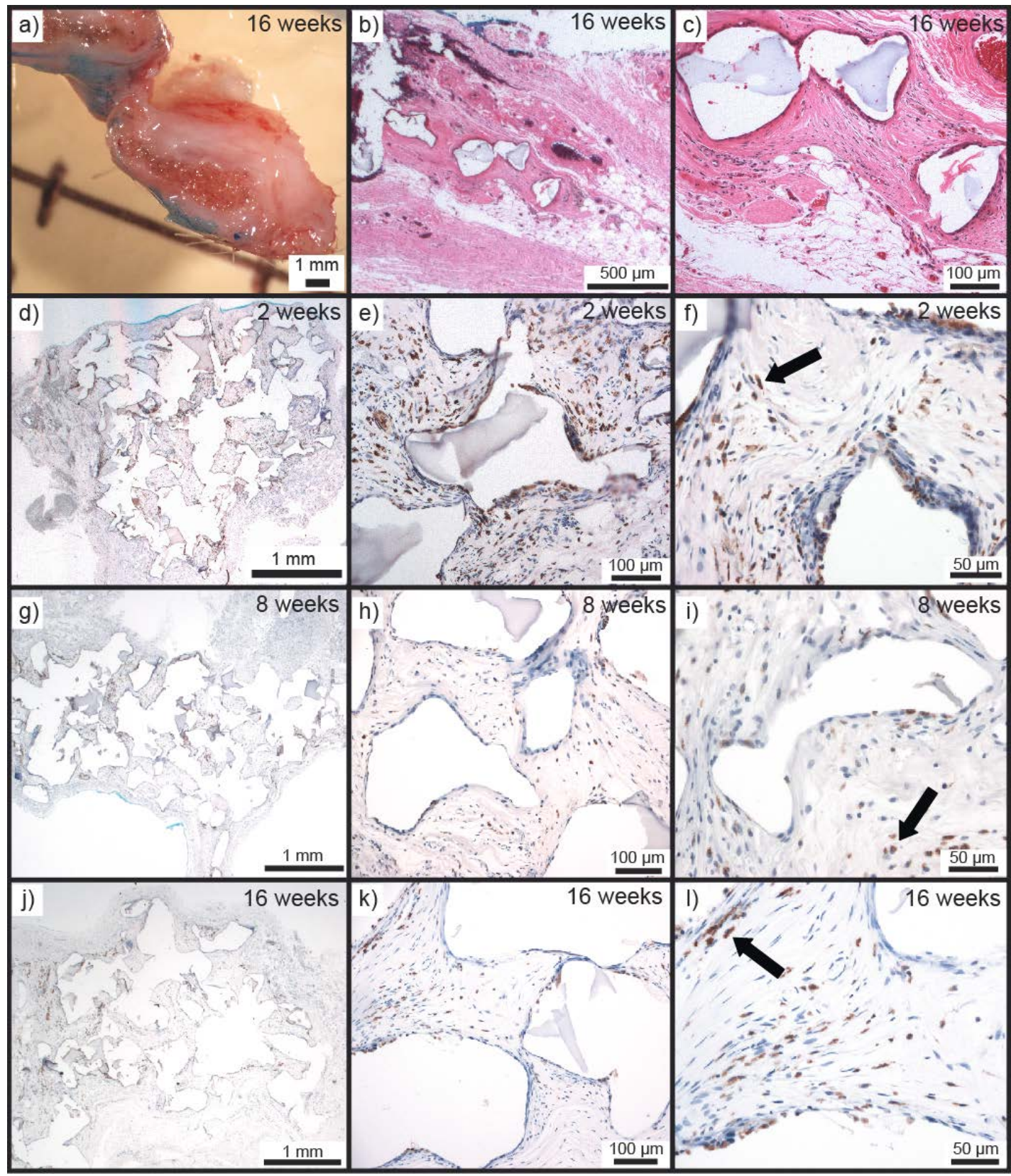

Figure 6. (a) Macroscopic cross-section of Seb- $\mathrm{PEH}_{2}$ removed at 16 weeks. H\&E stained section of tissue where Seb-PEH 2 was implanted (note minimal PEH remnants were observed) at (b) $1.25 \times$ and (c) $10 \times$ magnification. ED1 stained sections of Seb-PEH $\mathrm{PH}_{2}$ removed at 2 weeks at (d) $1.25 \times$, (e) $10 \times$, and (f) $20 \times$ magnification. ED1 stained sections of Seb- $\mathrm{PEH}_{2}$ removed at 8 weeks at (g) $1.25 \times$, (h) $10 \times$, and (i) $20 \times$ magnification (note the reduced macrophage numbers indicated by reduced staining at 8 weeks compared to 2 weeks). ED1 stained section of tissue in the Seb-PEH $\mathrm{H}_{2}$ implantation site at 16 weeks at (j) $1.25 \times$, (k) $10 \times$, and (1) $20 \times$ magnification. (ED1 stained macrophages are indicated by arrows).

\section{Conclusions}

Porous polyester-ether hydrogels (PEHs) with tunable properties were produced as porous tissue engineering scaffolds using a facile, rapid, and scalable synthetic approach. A salt leaching technique was utilized to control pore sizes. Three acid chloride cross-linkers, sebacoyl, succinyl, and trimesoyl chlorides were used for hydrogel fabrication. Use of different cross-linkers allowed the fabrication of hydrogels with different swelling, mechanical, and degradation properties. The covalent incorporation 
of various amounts of PCL was also employed to tailor the compressive and swelling capabilities of the PEHs. In combination, these parameters provide the means to tune the swelling, degradation rates, and mechanical properties of the hydrogels allowing specific tailoring of scaffolds for various tissue types. In vitro degradation studies and implantation in vivo demonstrated the biodegradability of the PEHs, with major degradation over 16 weeks for implanted Seb-PEHs. In vitro studies using PEH conditioned media and PEH degradation products revealed negligible effect on cell proliferation at low and high concentrations. In vivo, no toxicity or adverse effects were observed and the rapid penetration of vascular tissue to the centre of the hydrogels was observed within 2 weeks. ED1 staining for macrophages revealed that the Seb-PEHs incite minimal inflammatory responses that are reduced from 2 weeks onwards, and are minimised by 8 weeks. Even after major degradation at 16 weeks, no adverse effects from the PEH degradation products were noted, as indicated by the minimal presence of macrophages. The use of commercially available and cheap precursors also demonstrates the PEHs' suitability for large scale production. With desirable biodegradable, biocompatibility, and minimal inflammatory response, as well as high permeability to tissue and vascularisation, the PEHs are promising candidates for tissue augmentation and breast reconstruction.

Acknowledgments: Andrea O'Connor (Department of Chemical and Biomolecular Engineering, The University of Melbourne) for use of facilities, Phong Tran (Department of Chemical and Biomolecular Engineering, The University of Melbourne) for assistance with in vitro cell viability assays, Mr. Roger Curtain (Advanced Microscopy Facility, Bio21) for assistance with scanning electron microscopy, O'Brien Institute for providing facilities for in vivo studies and histological analysis. The authors acknowledge The University of Melbourne and the Australian Research Council (ARC) for scholarship and fellowship support (BO: Melbourne Research Scholarship; GGQ: ARC Future Fellowship FT (FT110100411); KL: ARC Super Science Fellowship (FS110200025)); W.A.M: NHMRC project Grant: GNT1064786.

Author Contributions: Berkay Ozcelik, Katharina Ladewig, Geoffrey W. Stevens, Keren Abberton, Wayne A. Morrison, Anton Blencowe and Greg G. Qiao conceived and designed the experiments; Berkay Ozcelik, Katharina Ladewig and Jason Palmer performed the experiments; Berkay Ozcelik, Jason Palmer, Katharina Ladewig, Keren Abberton, and Anton Blencowe analyzed the data; Berkay Ozcelik, Jason Palmer, Katharina Ladewig, Paula Facal Marina, Keren Abberton, and Anton Blencowe wrote the paper.

Conflicts of Interest: The authors declare no conflict of interest.

\section{References}

1. El-Sherbiny, I.M.; Yacoub, M.H. Hydrogel scaffolds for tissue engineering: Progress and challenges. Glob. Cardiol. Sci. Pract. 2013, 2013, 316-342. [CrossRef] [PubMed]

2. O'Brien, F.J. Biomaterials and scaffolds for tissue engineering. Mater. Today 2011, 14, 88-95. [CrossRef]

3. Zhu, J.; Marchant, R.E. Design properties of hydrogel tissue-engineering scaffolds. Expert Rev. Med. Devices 2011, 8, 607-626. [CrossRef] [PubMed]

4. Nemir, S.; West, J.L. Synthetic materials in the study of cell response to substrate rigidity. Ann. Biomed. Eng. 2010, 38, 2-20. [CrossRef] [PubMed]

5. Zhu, J. Bioactive modification of poly(ethylene glycol) hydrogels for tissue engineering. Biomaterials 2010, 31, 4639-4656. [CrossRef] [PubMed]

6. Lin, C.-C.; Anseth, K.S. PEG Hydrogels for the controlled release of biomolecules in regenerative medicine. Pharm. Res. 2009, 26, 631-643. [CrossRef] [PubMed]

7. Hern, D.L.; Hubbell, J.A. Incorporation of adhesion peptides into nonadhesive hydrogels useful for tissue resurfacing. J. Biomed. Mater. Res. 1998, 39, 266-276. [CrossRef]

8. Rizzi, S.C.; Hubbell, J.A. Recombinant protein-co-PEG networks as cell-adhesive and proteolytically degradable hydrogel matrixes. Part I: Development and physicochemical characteristics. Biomacromolecules 2005, 6, 1226-1238. [CrossRef] [PubMed]

9. Rizzi, S.C.; Ehrbar, M.; Halstenberg, S.; Raeber, G.P.; Schmoekel, H.G.; Hagenmüller, H.; Müller, R.; Weber, F.E.; Hubbell, J.A. Recombinant protein-co-PEG networks as cell-adhesive and proteolytically degradable hydrogel matrixes. Part II: Biofunctional characteristics. Biomacromolecules 2006, 7, 3019-3029. [CrossRef] [PubMed]

10. Zustiak, S.P.; Leach, J.B. Hydrolytically degradable poly(ethylene glycol) hydrogel scaffolds with tunable degradation and mechanical properties. Biomacromolecules 2010, 11, 1348-1357. [CrossRef] [PubMed] 
11. Hamid, Z.A.A.; Blencowe, A.; Ozcelik, B.; Palmer, J.A.; Stevens, G.W.; Abberton, K.M.; Morrison, W.A.; Penington, A.J.; Qiao, G.G. Epoxy-amine synthesised hydrogel scaffolds for soft-tissue engineering. Biomaterials 2010, 31, 6454-6467. [CrossRef] [PubMed]

12. Boehnke, N.; Cam, C.; Bat, E.; Segura, T.; Maynard, H.D. Imine hydrogels with tunable degradability for tissue engineering. Biomacromolecules 2015, 16, 2101-2108. [CrossRef] [PubMed]

13. Rydholm, A.E.; Bowman, C.N.; Anseth, K.S. Degradable thiol-acrylate photopolymers: Polymerization and degradation behavior of an in situ forming biomaterial. Biomaterials 2005, 26, 4495-4506. [CrossRef] [PubMed]

14. Rydholm, A.E.; Reddy, S.K.; Anseth, K.S.; Bowman, C.N. Controlling network structure in degradable thiol-acrylate biomaterials to tune mass loss behaviour. Biomacromolecules 2006, 7, 2827-2836. [CrossRef] [PubMed]

15. Tan, S.; Blencowe, A.; Ladewig, K.; Qiao, G.G. A novel one-pot approach towards dynamically cross-linked hydrogels. Soft Matter 2013, 9, 5239-5250. [CrossRef]

16. Malkoch, M.; Vestberg, R.; Gupta, N.; Mespouille, L.; Dubois, P.; Mason, A.F.; Hedrick, J.L.; Liao, Q.; Frank, C.W.; Kingsbury, K.; et al. Synthesis of well-defined hydrogel networks using Click chemistry. Chem. Commun. 2006, 2774-2776. [CrossRef]

17. Hodgson, S.M.; Bakaic, E.; Stewart, S.A.; Hoare, T.; Adronov, A. Properties of poly(ethylene glycol) hydrogels cross-linked via strain-promoted alkyne-azide cycloaddition (SPAAC). Biomacromolecules 2016, 17, 1093-1100. [CrossRef] [PubMed]

18. Seck, T.M.; Melchels, F.P.; Feijen, J.; Grijpma, D.W. Designed biodegradable hydrogel structures prepared by stereolithography using poly(ethylene glycol)/poly(D,L-lactide)-based resins. J. Control. Release 2010, 148, 34-41. [CrossRef] [PubMed]

19. Elbert, D.L.; Pratt, A.B.; Lutolf, M.P.; Halstenberg, S.; Hubbell, J.A. Protein delivery from materials formed by self-selective conjugate addition reactions. J. Control. Release 2001, 76, 11-25. [CrossRef]

20. Zhang, C.; Sangaj, N.; Hwang, Y.; Phadke, A.; Chang, C.W.; Varghese, S. Oligo(trimethylene carbonate)poly(ethylene glycol)-oligo(trimethylene carbonate) triblock-based hydrogels for cartilage tissue engineering. Acta Biomater. 2011, 7, 3362-3369. [CrossRef] [PubMed]

21. Lin, C.-C.; Raza, A.; Shih, H. PEG hydrogels formed by thiol-ene photo-click chemistry and their effect on the formation and recovery of insulin-secreting cell spheroids. Biomaterials 2011, 32, 9685-9695. [CrossRef] [PubMed]

22. Hollister, S.J.; Murphy, W.L. Scaffold translation: Barriers between concept and clinic. Tissue Eng. Part B Rev. 2011, 17, 459-474. [CrossRef] [PubMed]

23. Techanukul, T.; Lohsiriwat, V. Stem cell and tissue engineering in breast reconstruction. Gland Surg. 2014, 3, 55-61. [PubMed]

24. Visscher, L.E.; Cheng, M.; Chhaya, M.; Hintz, M.L.; Schantz, J.-T.; Tran, P.; Ung, O.; Wong, C.; Hutmacher, D.W. Breast augmentation and reconstruction from a regenerative medicine point of view: State of the art and future perspectives. Tissue Eng. Part B Rev. 2017, 23, 281-293. [CrossRef] [PubMed]

25. Chhaya, M.P.; Balmayor, E.R.; Hutmacher, D.W.; Schantz, J.-T. Transformation of breast reconstruction via additive biomanufacturing. Sci. Rep. 2016, 6, 28030. [CrossRef] [PubMed]

26. Do, A.V.; Khorsand, B.; Geary, S.M.; Salem, A.K. 3D printing of scaffolds for tissue regeneration applications. Adv. Healthc. Mater. 2015, 4, 1742-1762. [CrossRef] [PubMed]

27. Combellack, E.J.; Jessop, Z.M.; Naderi, N.; Griffin, M.; Dobbs, T.; Ibrahim, A.; Evans, S.; Burnell, S.; Doak, S.H.; Whitaker, I.S. Adipose regeneration and implications for breast reconstruction: Update and the future. Gland Surg. 2016, 5, 227-241. [PubMed]

28. Flynn, L.; Woodhouse, K.A. Adipose tissue engineering with cells in engineered matrices. Organogenesis 2008, 4, 228-235. [CrossRef] [PubMed]

29. Patrick, C.W.; Chauvin, P.B.; Hobley, J.; Reece, G.P. Preadipocyte seeded PLGA scaffolds for adipose tissue engineering. Tissue Eng. 1999, 5, 139-151. [CrossRef] [PubMed]

30. Alhadlaq, A.; Tang, M.; Mao, J.J. Engineered adipose tissue from human mesenchymal stem cells maintains predefined shape and dimension: Implications in soft tissue augmentation and reconstruction. Tissue Eng. 2005, 11, 556-566. [CrossRef] [PubMed]

31. Stosich, M.S.; Mao, J.J. Adipose tissue engineering from human adult stem cells: Clinical implications in plastic and reconstructive surgery. Plast. Reconstr. Surg. 2007, 119, 71-85. [CrossRef] [PubMed] 
32. Brandl, F.P.; Seitz, A.K.; Tessmar, J.K.; Blunk, T.; Göpferich, A.M. Enzymatically degradable poly(ethylene glycol) based hydrogels for adipose tissue engineering. Biomaterials 2010, 31, 3957-3966. [CrossRef] [PubMed]

33. Wang, Z.; Li, S.; Wang, L.; Zhang, S.; Jiang, Y.; Chen, J.; Luo, D. Polyacrylamide hydrogel injection for breast augmentation: Another injectable failure. Med. Sci. Monit. 2012, 18, CR399. [CrossRef] [PubMed]

34. Cheung, H.K.; Han, T.T.; Marecak, D.M.; Watkins, J.F.; Amsden, B.G.; Flynn, L.E. Composite hydrogel scaffolds incorporating decellularized adipose tissue for soft tissue engineering with adipose-derived stem cells. Biomaterials 2014, 35, 1914-1923. [CrossRef] [PubMed]

35. Castells-Sala, C.; Martínez-Ramos, C.; Vallés-Lluch, A.; Pradas, M.M.; Semino, C. In vitro development of bioimplants made up of elastomeric scaffolds with peptide gel filling seeded with human subcutaneous adipose tissue-derived progenitor cells. J. Biomed. Mater. Res. Part A 2015, 103, 3419-3430. [CrossRef] [PubMed]

36. Ozcelik, B.; Blencowe, A.; Palmer, J.; Ladewig, K.; Stevens, G.W.; Abberton, K.M.; Morrison, W.A.; Qiao, G.G. Highly porous and mechanically robust polyester poly(ethylene glycol) sponges as implantable scaffolds. Acta. Biomater. 2014, 10, 2769-2780. [CrossRef] [PubMed]

37. Ozcelik, B.; Brown, K.D.; Blencowe, A.; Ladewig, K.; Stevens, G.W.; Scheerlinck, J.P.; Abberton, K.; Daniell, M.; Qiao, G.G. Biodegradable and biocompatible poly(ethylene glycol)-based hydrogel films for the regeneration of corneal endothelium. Adv. Healthc. Mater. 2014, 3, 1496-1507. [CrossRef] [PubMed]

38. Kim, J.; Lee, K.-W.; Hefferan, T.E.; Currier, B.L.; Yaszemski, M.J.; Lu, L. Synthesis and evaluation of novel biodegradable hydrogels based on poly(ethylene glycol) and sebacic acid as tissue engineering scaffolds. Biomacromolecules 2008, 9, 149-157. [CrossRef] [PubMed]

39. Murphy, W.L.; Dennis, R.G.; Kileny, J.L.; Mooney, D.J. Salt fusion: An approach to improve pore interconnectivity within tissue engineering scaffolds. Tissue Eng. 2002, 8, 43-52. [CrossRef] [PubMed]

40. Saez-Martinez, V.; Atorrasagasti, G.; Olalde, B.; Madarieta, I.; Morin, F.; Garagorri, N. Fabrication and characterization of macroporous poly(ethylene glycol) hydrogels generated by several types of porogens. Int. J. Polym. Mater. Polym. Biomater. 2013, 62, 502-508. [CrossRef]

41. Dehghani, F.; Annabi, N. Engineering porous scaffolds using gas-based techniques. Curr. Opin. Biotechnol. 2011, 22, 661-666. [CrossRef] [PubMed]

42. Yamamoto, M.; Tabata, Y.; Kawasaki, H.; Ikada, Y. Promotion of fibrovascular tissue ingrowth into porous sponges by basic fibroblast growth factor. J. Mater. Sci. Mater. Med. 2000, 11, 213-218. [CrossRef] [PubMed]

43. Yang, S.F.; Leong, K.F.; Du, Z.H.; Chua, C.K. The design of scaffolds for use in tissue engineering. Part I. Traditional factors. Tissue Eng. 2001, 7, 679-689. [CrossRef] [PubMed]

44. Vedadghavami, A.; Minooei, F.; Mohammadi, M.H.; Khetani, S.; Rezaei Kolahchi, A.; Mashayekhan, S.; Sanati-Nezhad, A. Manufacturing of hydrogel biomaterials with controlled mechanical properties for tissue engineering applications. Acta Biomater. 2017, 62, 42-63. [CrossRef] [PubMed]

45. Akhtar, R.; Sherratt, M.J.; Cruickshank, J.K.; Derby, B. Characterizing the elastic properties of tissues. Mater. Today 2011, 14, 96-105. [CrossRef]

46. McKee, C.T.; Last, J.A.; Russell, P.; Murphy, C.J. Indentation versus tensile measurements of Young's modulus for soft biological tissues. Tissue Eng. Part B Rev. 2011, 17, 155-164. [CrossRef] [PubMed]

47. Rodriguez-Galan, A.; Franco, L.; Puiggali, J. Degradable poly(ester amide)s for biomedical applications. Polymers 2011, 3, 65-99. [CrossRef]

48. Zhou, X.-M. Synthesis and characterization of polyester copolymers based on poly(butylene succinate) and poly(ethylene glycol). Mater. Sci. Eng. C 2012, 32, 2459-2463. [CrossRef]

49. Bailon, P.; Berhtold, W. Polyethylene glycol-conjugated pharmaceutical proteins. Pharm. Sci. Technol. Today 1998, 1, 352-356. [CrossRef]

50. Li, B.Q.; Dong, X.; Fang, S.H.; Gao, J.Y.; Yang, G.Q.; Zhao, H. Systemic toxicity and toxicokinetics of a high dose of polyethylene glycol 400 in dogs following intravenous injection. Drug. Chem. Toxicol. 2011, 34, 208-212. [CrossRef] [PubMed]

51. Gong, C.Y.; Shi, S.; Dong, P.W.; Yang, B.; Qi, X.R.; Guo, G.; Gu, Y.C.; Zhao, X.; Wei, Y.Q.; Qian, Z.Y. Biodegradable in situ gel-forming controlled drug delivery system based on thermosensitive PCL-PEG-PCL hydrogel: Part 1-Synthesis, characterization, and acute toxicity evaluation. J. Pharm. Sci. 2009, 98, 4684-4694. [CrossRef] [PubMed]

52. Wang, Y.; Ameer, G.A.; Sheppard, B.J.; Langer, R. A tough biodegradable elastomer. Nat. Biotechnol. 2002, 20, 602-606. [CrossRef] [PubMed] 
53. Oliveira, M.L.N.; Franco, M.R. Solubility of 1,4-butanedioic acid in aqueous solutions of ethanol or 1-propanol. Fluid Phase Equilib. 2012, 326, 50-53. [CrossRef]

54. Nagata, M.; Sugiura, R.; Sakai, W.; Tsutsumi, N. Synthesis and characterization of biodegradable network poly(ethylene glycol) films with elastic properties. J. Appl. Polym. Sci. 2007, 106, 2885-2891. [CrossRef]

55. Sun, H.; Mei, L.; Song, C.; Cui, X.; Wang, P. The in vivo degradation, absorption and excretion of PCL-based implant. Biomaterials 2006, 27, 1735-1740. [CrossRef] [PubMed]

56. Laschke, M.W.; Menger, M.D. Vascularization in tissue engineering: Angiogenesis versus inosculation. Eur. Surg. Res. 2012, 48, 85-92. [CrossRef] [PubMed]

57. Bramfeldt, H.; Sabra, G.; Centis, V.; Vermette, P. Scaffold vascularization: A challenge for three-dimensional tissue engineering. Curr. Med. Chem. 2010, 17, 3944-3967. [CrossRef] [PubMed]

58. Lee, S.; Zhang, J. Heterogeneity of macrophages in injured trigeminal nerves: Cytokine/chemokine expressing vs. phagocytic macrophages. Brain Behav. Immun. 2012, 26, 891-903. [CrossRef] [PubMed]

(C) 2018 by the authors. Licensee MDPI, Basel, Switzerland. This article is an open access article distributed under the terms and conditions of the Creative Commons Attribution (CC BY) license (http://creativecommons.org/licenses/by/4.0/). 